\title{
J
}

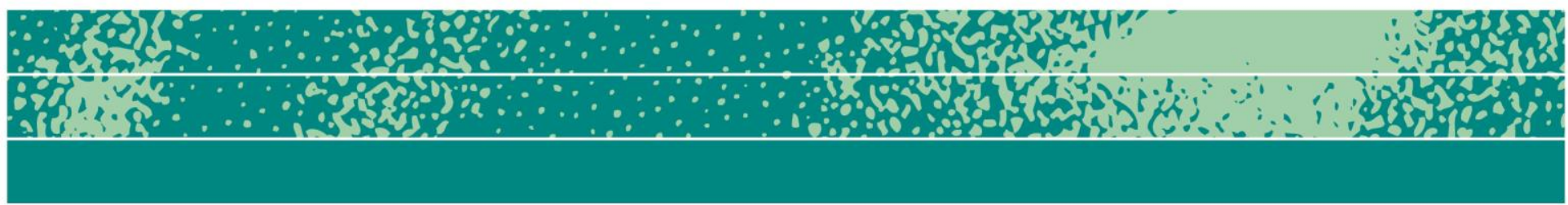

\section{Opinions: All About Culture}

\author{
Edgar Schein, Jana Costas \& Gideon Kunda, Majken Schultz, Tomoko \\ Hamada Connolly, Susan Wright, Gert Jan Hofstede, and Dixon \\ Wong Heung Wah
}

\section{Some thoughts about the uses and misuses of the concept of culture}

Edgar H. Schein (MIT Sloan School of Management)

Page 1 of 45

JBA 4(1): 106-150

Spring 2015

(C) The Author(s) 2015

ISSN 2245-4217

www.cbs.dk/jba

The word "culture" has been used in so many ways in the last few decades that it has virtually lost all meaning. In this short opinion piece, I want to bring back the concept of culture, as it has been used by anthropologists, and show its power when used in relation to nations, organizations and occupations.

The multiple uses of the word culture today have led me to reinforcing a concept drawn from anthropology that is applicable to organizations and occupations (Schein, 1985, 2010). I think culture is a property of a group of some sort, reflecting the shared learning that the members have experienced in their efforts to survive, grow, and remain internally integrated. Culture thus always has shared components that deal with managing the external environment and other components that deal with the rules and norms of how to get along inside the group. One of the commonest mistakes in recent usage is to link culture only to the inside "how we get along" components.

I had the good fortune as a social psychologist to get my Ph.D. at 
Harvard's Department of Social Relations in the 1949-1952 period, when the Departments of Anthropology, Sociology, Clinical and Social Psychology decided to merge and expose Ph.D. students to all four disciplines. I therefore was exposed to the thinking of Clyde and Florence Kluckhohn who were trying to make us understand not only how to think about culture, but also how to use culture as a concept that permitted the comparison of a number of cultures that co-existed in the U.S. west-several Indian cultures, Mormons, and "Anglos." I developed a deep respect for the concept both from classes and from my interaction with fellow students who had lived with the Navahos. I also got to know Margaret Singer, a clinical psychologist who told us many stories of the difficulties of delivering medical care in the Utah area because the different cultural groups had very different rules and norms about exposing the body, taking pills, and so on.

I mention all of this because, when I later encountered organizations, I approached trying to understand the cultural elements from this same broader anthropological perspective. When my job at MIT facilitated doing some consulting, I had the further good fortune of working simultaneously in a very Yankee computer company (Digital Equipment Corp., DEC) during its early start-up years and throughout its history to its end 30 years later; and, at the same time, spent five years with Ciba-Geigy, a large Swiss-German Chemical company. The huge cultural contrasts that I experienced could be attributed to the national differences between Yankee U.S. versus Swiss-German Switzerland; to the differences in age between a young company and very old one; to the differences in the technologies and resulting occupations of the employees and managers (chemical versus electrical engineers); and to their organizational histories based on founder values and subsequent historical experiences. All four factors were in play.

When I first wrote about "organizational culture" in 1985, what struck me most about my work with these two companies was that we could reconstruct quite a lot about their actual histories, and could, in fact, even observe some of that history in the here-and-now by watching the founders and leaders in action (Schein, 1985). I was intrigued by the fact that most anthropological accounts of cultures could only speculate about the origins of what they observed. In the case of DEC, I could actually watch a founder/entrepreneur create a culture in imposing on his employees his model of how the organization should function by whom he hired, by how he trained and managed them, and by the kind of structure and processes he created to support his values. In the case of CG, I knew less of its history and founding, but was hired by a CEO who wanted to start some new ways of thinking in a very settled and highly structured organization whose culture went back a long way, involved a merger, and was well embedded in the "Basel aristocracy." DEC illustrated how culture formed, C-G illustrated how stable culture can become and how hard it is to change any one element of it. 
How were we to figure out whether "organizational culture" made any sense in this cognitively diverse landscape? Two further sets of data helped to sort this out. Every DEC office or plant I ever visited, whether in Finland, Germany, Switzerland or Singapore sounded and felt just like the HQs office in Maynard, MA. I could easily see how national culture further influenced the local scene, but there was no question that DEC had a unique feel and identity that could not be explained by local culture.

In C-G I had a related experience. I had been asked to interview and observe $\mathrm{C}$-G employees and managers to learn about and describe "the $\mathrm{C}$ G culture," concentrating on the Basel HQs. A year or so later, I was working in the U.S. with the C-G subsidiary and was asked to give a lecture to the U.S. management about what I had learned in my Basel research. I described the C-G culture as I understood it and had written about it. The reaction in New Jersey was shock. They said, "My God, you have just described us." Until that time they had had no sense of how much their local norms, values, and behaviour patterns were basically the same as the Basel ones.

In my studies of indoctrination of POWS and civilians by the Chinese communists in the 1950s, I learned that if people cannot easily exit an organization, they will either socialize themselves into what they perceive the norms to be, or will be explicitly indoctrinated (Schein, 1961). DEC actually ran "boot comps" where new employees were taught the right way to think, feel and behave, if they wanted to make it in DEC. One of my students later wrote about culture as a socializing and coercive control force (Kunda, 2006). I could easily see such coercive socialization processes in both companies, and could see how conformity was created both by those processes and by the exit of people who did not fit.

The conceptual problem was how to express what I had learned in the field as a consultant in academically and practically useful language. The solution was to describe how culture is created by observing this process over several decades in DEC and finding similar stories in the literature about other companies. The three-level model I ended up with is basically a sequential model presented at one point in time (Schein, $1985,2003,2010$ ). The founder, entrepreneur and early leaders impose their will on their organization and create what we can think of as "artifacts," the visible shared components-behavioural rules, structures, processes, symbols, buildings, and so on. At this point it would be wrong to call this a culture, because we don't know whether what was imposed has survival value. Lots of organizations don't make it.

However, and this point is crucial, if what the leaders have imposed works-if the organization is successful both externally in terms of its products and services, and internally in terms of its management system-a subtle cognitive transformation begins to take place in the employees. They come to believe that they've got it right. It worked and continues to work. So what were originally the founder's personal values 
now come to be seen as valid, as correct, and, therefore, to be perpetuated and taught to newcomers. Some of those values come to be appreciated and named as official values, what I called the level of "espoused values." We might now be tempted to say that those espoused values are the culture, but then I encountered some further data that made that impossible as well.

The espoused values were usually a list of very abstract concepts like "integrity," "team work," "quality" which, however, often did not mesh with what I observed in the actual behaviour of members of the organization. Something deeper was "driving" the observed behaviour. In order, therefore, to describe what I saw to be the stable elements of the "culture" of the organization required a three level model:

1. The level of artifacts, by which I meant everything you see and feel when you enter the organization (or country), the behavioural "how we do things around here."

2. The level of espoused values, by which I meant what the organization claims it is and wants to be-which may or may not mesh with the observed behaviour and other artifacts such as the structures and processes in place. I often observed that there were strong disconnects between the artifacts and some of the claimed values. How then do we explain stable artifacts, processes and structures? What is maintaining them? There must be a deeper level that "drives" the behaviour, which is not necessarily public, visible or even conscious if the organization has a history of several generations of managers and employees.

3. The level of shared tacit assumptions, which were at one time explicit values but, because they worked so well, became taken for granted and increasingly non-negotiable.

To me this is easiest to illustrate in the U.S. where countless organizations will espouse team work and group values, but all of the artifacts and the observed decision process are based on individual performance, especially the critical processes of how people are hired, trained, paid, promoted, and otherwise treated. The notion of "group pay" or "group accountability" is considered unthinkable. It is inescapable, therefore, that one of the shared tacit assumptions underlying most U.S. companies, and certainly DEC, was "rugged individualism," and "individual competition is the key to success."

I was able to reconstruct the patterns of interlocking shared tacit assumptions of DEC and C-G and built my early writings about organizational culture around the explication of this model (Schein, 1985, 2003,2010 ). The most important word is "shared." I made this part of the definition of culture to give the word "culture" a specific meaning, and argued that culture is a learned response to survival in the environment 
and the need for internal integration. I felt that this definition jibed best with what the anthropologists described in their ethnographies.

The question then arose of what we do when we see an organization in which some things are shared, but others are not, and there are all kinds of conflicts in the organization. There are always two possibilities in this situation-that there really are no shared tacit assumptions; that no culture has formed at the total organizational level; or that there are very few overall "corporate" shared assumptions, but lots of groups within the organization who have for various reasons evolved their own subcultures with their own artifacts, espoused values, and shared tacit assumptions. We then have to view the total organization as a "multi-cultural system."

What we then discover is that the growth of these "subcultures" is very much related to the age, size, and success of the total organization (Schein, 2003). It also then becomes an empirical question whether, in an organization with many subcultures, one can even talk about an organizational or corporate culture (Martin, 2002). There will, undoubtedly, be some shared tacit assumptions having to do with the basic mission, products, and services that the organization provides, but many of the shared processes, structures, and behaviour patterns may turn out to have more to do with national culture. For example, in the U.S., the assumption of rugged competitive individualism will probably be found in most companies. But the examination of the subcultures will be no less important because that will reveal that the most important driver of behaviour derives neither from country nor organization, but from occupation (Schein, 2010). This point of view meshes well with the tradition started by Everett Hughes of studying various occupations about which we knew relatively little (Hughes, 1958; Becker, 1963).

As I think about it now, the best way to "explain" the DEC culture is to say that it is how young electrical engineers think and act, and the best way to think about C-G is to consider how chemists and chemical engineers think and act. The country cultures and the company experiences clearly influenced this, but the core of the culture, the DNA of it, lies in the kind of thinking that the members of these occupations learn worldwide.

My recent work has been in "safety," which has taken me into nuclear plants and hospitals (Schein, 2013; Amalberti, 2013). What I found in the nuclear industry is the domination of nuclear engineers; the obsession with understanding the uniqueness of nuclear technology; and the fear that, if someone other than a nuclear engineer runs the plant or the site on which the plant sits, safety problems may increase. In the field of patient safety, I find that the biggest problems are the communication failures between doctors, nurses, and techs-especially where you have not only the different occupational cultures of doctors and nurses, but also the additional fact that they have different status and rank in most 
societies.

I have found that to understand a hospital's culture, the most important thing is to understand the subcultures of medicine, nursing and administration. If a change program is to be launched to improve effectiveness and safety, my consultant friends argue that one must begin with changing the "compact" between the doctors and the administration, which is de facto saying that both groups have to examine their cultures, their "taken for granted" assumptions about what to give and what to get from each other, and renegotiate toward something that both can accept (Kornacki \& Silversin, 2012). A recent ethnographic study of the implementation in hospitals of the rule that resident should not work more than 80 hours brings out how the different subgroups engage in their effort to resist or foster the change (Kellogg, 2011).

As a final example, I note that when the computer industry went from hardware to software innovation, even the concept of "engineer" changed from hardware types to software types. The kinds of people who now populate Facebook and Google are occupationally a different breed. Creative programmers may well be the ultimately cosmopolitan occupation, which may produce cultural assumptions that are shared worldwide and evolve quite independently of both national and organizational forces.

In focusing on national, organizational, and occupational cultures, I have deliberately tried to highlight the stable elements of culture, the tacit, taken for granted assumptions, the skeleton, so to speak, which changes slowly. An alternative view of culture is that it is constantly being renegotiated in the present interactions of members of groups, organizations, nations, occupations, and in all the temporary relationships that exist between them (Smirchich, 1983). I could see how, in both DEC and $\mathrm{C}-\mathrm{G}$, the daily interactions displayed the culture, and also how culture evolved slowly as new leaders and members changed some of the characteristics of those interactions. I had also observed culture creation and evolution in the many sensitivity training groups I had run for the National Training Labs in Bethel, Maine. I could see that, within a few hours, the shared experience of the group created norms and special meanings, which a newcomer to the group could not understand, and I could see how the newcomer's arrival forced evolution of some of those norms and meanings.

In retrospect, my decision to go for the more structured anthropological definition of culture was based on the decision that the dynamic here-and-now view of culture formation and evolution could be incorporated into the structural model, while the reverse was not true. The emergent meaning point of view did not "explain" the obvious stability of organizations and the difficulty of "changing culture." I find the biological analogy useful here, in that my bones and early memories are pretty stable while I am still learning new things, constantly 
reformulating ideas, and constantly rediscovering that the only new things that make sense fit somehow into the structures that are already there. Both with culture and with personality/character I find the verb "evolve" more appropriate than the verb "change." Elements of culture can change, but the deeper levels can only evolve.

As we look ahead, it seems to me that where we have seen and will continue to see the most such evolution will be in the occupational cultures that spring up around new technologies. The social media and the new forms of information technology that are being created will bring with them new skill sets that create new occupations, and those new occupations will evolve basic assumptions that may be quite different from what the occupational cultures of today reveal. For example, as we watch the next generation "locked" onto screens engaging in rapid multitasking of the sort that video games require, I note that while some parents deplore the lost ability to "go deeper" into a subject, I find myself wondering whether the external world with its growing number of social media requires rapid multi-tasking as a minimum competence for survival. We might be made uncomfortable by these changes, but they may be necessary. As I watch my grandchildren, I realize that they are growing up into a world that I neither understand nor can change. My best option is to watch them closely and learn from them.

In conclusion, I believe the concept of culture can be an important and meaningful construct in organizational psychology and sociology but only if we capture in the definition both the multi-level complexity and dynamic evolutionary quality of the concept.

\section{References}

Amalberti, R. (2013) Navigating safety. New York: Springer.

Becker, H. S. (1963) Outsiders. New York: The Free Press.

Gerstein, M. S. \& Schein, E. H. (2011) "Dark Secrets: Face-Work, Organizational Culture and Disaster Prevention." In C. de Franco and C. O. Meyer, Eds. Forecasting Warning and Responding to Transnational Risks. London: Palgrave Macmillan, pp. 148-165.

Hughes, E. C. (1958) Men and their work. Glencoe, IL: Free Press.

Kellogg, K. C. (2011) Challenging operations. Chicago: University of Chicago Press.

Kornacki, M. J. \& Silversin, J. (2012) Leading physicians through change. Tampa, FL: American College of Physician Executives.

Kunda, G. (2006) Engineering Culture. Revised Edition. Philadelphia, PA: Temple University Press. 
Martin, J. (2002) Organizational culture: Mapping the terrain. Newbury Park, CA: Sage.

Schein, E. H. (1961) Coercive Persuasion. New York: Norton.

Schein, E. H. (1985) Organizational culture and leadership. San Francisco: Jossey Bass.

Schein, E. H. (2003) DEC is dead; Long live DEC. San Francisco:

Berrett/Kohler.

Schein, E. H. (2010) Organizational culture and leadership. Fourth Edition. San Francisco: Jossey-Bass, Wiley.

Schein, E. H. (2013) Humble Inquiry. San Franscisco: Berrett/Kohler.

Schein, E. H. (2013) "The culture factor in safety culture." In Safety management in context. White Book. Zurich, Switzerland: ETH, MIT, and Swiss Re Center for Global Dialogue. pp. 75-80.

Smirchich, L. (1983) "Concepts of culture and organizational analysis." Administrative Science Quarterly, 28, 339-358.

\section{When I Hear the Word Culture... I reach for my gun ${ }^{1}$}

Jana Costas (European University Viadrina) and Gideon Kunda (Tel Aviv University)

This well-known, provocative statement was the first phrase that came to mind when considering the invitation to reflect and write on our experience in applying the term culture to business and organizational settings. As a cursory browse through the web reveals, it is a phrase that has captured the imagination of commentators on matters cultural, in settings as diverse as popular music, theatre, cinema, and the sciences, and is oft repeated and widely quoted with little awareness of its rather dark origins: the play Schlageter by the Nazi playwright Hanns Johst. Why, we asked ourselves, does this ominous connection between culture and the gun appear so appealingly, if perhaps ironically, insightful and intuitively relevant to our topic? Why does it evoke an immediate response of recognition even though its significance remains, when the texts of its invokers are closely studied, frustratingly vague? Who exactly is, or should be, reaching for the gun? Against whom, and why? What

\footnotetext{
${ }^{1}$ Another translation is: "I release the safety on my Browning."
} 
exactly is its nature? And what, if anything, can students of culture learn from the juxtaposition, both metaphorical and literal, of culture and the gun?

We have in the past been engaged in studying organizations from a cultural perspective, and in teaching students and practitioners about this way of seeing and understanding the world, and we continue to do so. Our experience suggests-and indeed we believe-that "culture," with all its conceptual baggage, is an important, legitimate and indispensable concept, vital to our comprehension of the human condition in general, and business and organizational contexts in particular. And we continue to apply this concept in our work and everyday life. Yet we, too, when called upon to reflect on our experience with the term, found this stirring and evocative image strangely appropriate, even satisfying. Why?

While the exact meaning of the statement is far from self evident, its significance, we believe, lies in capturing how the concept of culture in general, and when applied to organizations in particular, is inextricably tied to-and in fact has its foundation in-battles, struggles and conflict, of both the real and symbolic sort. In this opinion piece, we want to unpack various ways in which the term culture has emerged from, been defined by, and used in the context of fighting-fighting over what is a legitimate way of being in the world; how and by whom it is to be determined; and what, if anything, one is to do about it. In doing so, we wish to cast light upon its troubling baggage, questionable usage and potential danger, as well as to reiterate our view of its continuing relevance for observers of, and actors in, the world of business and organizations.

There are several ways to look at the connection between culture and the gun: fighting with, fighting against, and fighting for culture.

\section{Fighting with culture}

The anthropological concept of culture, and its associated method ethnography, grew-it is commonly asserted-out of or in conjunction with the colonial encounter, broadly defined and understood. The close study of "others," often explicitly or implicitly labeled "primitive" or otherwise considered inferior, was predominantly built on the observer's assumption that one's culture and therefore oneself was inherently superior to those under study. This view justified changing, reforming, dominating, or even destroying existing social groupings and their ways of life, or at least assisting or not standing in the way of such projects. Despite a growing critical awareness of these origins, and efforts to correct its problematic implications, a similar stance seems still to dominate the world of those who study and use culture in organizational settings. Here the cultural perspective is often a manifestation of the widespread assumption that there is an inherently superior way of being (often labeled "management" or "leadership"), and that those associated 
with it have the right to make such a claim and act accordingly. If nothing else, the right to study the culture of the other, and to take steps to design or change it even if one claims a benevolent motive-progress, profit, efficiency, innovation-is itself the assertion of taken-for-granted privilege. Culture, therefore, can or should be managed and imposed on those regarded as inferior, in order to accomplish goals that those who speak in its name consider worthwhile. Culture, in this case, is either literally backed by a gun, or by the authority of those who, in the final analysis, assume, wittingly or not, its authorized presence on their side if all else fails. By using the term, deny it as one might, one therefore is either reaching for one's gun, or is inspired by and relies on those who, with the blessing of legitimate authority, can deem it necessary to do so. Conversely, and just as significantly, one might reasonably be suspected by the objects of one's study, should they find ways to critically consider their reality, of doing precisely this. They, in turn, might be motivated, or encouraged, to respond in kind. All the more reason, then, to keep one's gun, or gunmen, close at hand.

\section{Fighting against culture}

Those targeted by the proponents of culture and the wielders of its weapons might indeed take steps to defend themselves and in fact fight against the dismantling of old, and the creation and imposition of new, culture. The history of industrial conflict teaches us that facing authority is perhaps easier, or less confusing, when its agents do not disguise themselves, but make their means and goals overt. The more subtle and less overtly conflictual forms of culture management, characteristic of many organizations today-inspired, it would seem, by prevalent academic rhetoric and its underlying assumptions-represent an organized effort to regulate, shape, and control behaviour, experience, and indeed the self of employees in business and organizational settings. The use of the weapon of culture in the name of the common good often produces, or is thought to produce, collaboration, incorporation and acceptance, and can easily blind its objects to the subtly oppressive forms of control to which they are subjected. Here, too, with awareness comes humiliation, perhaps rage, sometimes resistance, but most often impotent cynicism: the final rebuke of and resignation to culture. When culture managers are at large, the gun, imagined or real, is not far away. Indeed we have ourselves felt the impulse to reach for it in organizations that tried, often with our tacit collaboration or full-blown support, to shape us in their organizational mold, or where we observed these processes at close range. In such cases, the gun-when reached for-may, and often has been, turned on anyone in range-from ourselves, through our peers and colleagues, to our managers. If nothing else, our experience indicates, and our moral and political position suggests, that the targets of culture studies would do well to prepare, and indeed arm themselves, 
conceptually at least, because their space, both external and internal, and with it their autonomy and dignity, might soon be under attack.

\section{Fighting for culture}

Given the troubling realities surrounding the study and use of culture, one might argue that these problems are inherent in the concept itself, and that, in order to avoid being coopted by those who fight with culture, and perhaps to support those who fight against it, it is best to discard the concept entirely. Indeed, in the course of our work, we have often felt this temptation ourselves. Despite these moments of despair, however, in the final analysis we believe that it is worthwhile fighting for the concept of culture, its well-documented potential for abuse notwithstanding. The subject matter of culture, we believe, is inherently part and parcel of social and organizational life, whether we choose to conceptualize it or not, study it or not, apply it or not. If we aim to comprehend social and organizational reality, for whatever purpose, it seems to us practically axiomatic then that we need to use, and that people naturally and intuitively use, cultural constructs. Indeed, the failure to do so leaves the study of human life in general, and of organizations in particular, at the mercy of "scientific," mechanistic, and deterministic perspectives, and those who stand to benefit from them.

With whom, then, and how must one do battle in the name of culture? The co-opters, misusers and detractors, academic and managerial, who, in the name of their interests often either deny or contaminate the conceptual space of culture, are an important if not easy target. An obvious effort is thus called for, Sisyphian though it may be, to engage in an ongoing critical study of the organizational contexts in which culture is propagated. This involves an effort, as it were, to turn culture studies upon its own institutions, its colleagues-both proponents and detractors of culture-and itself. Similarly, and just as obviously, it seems to us necessary to continually search for, recognize, explore, conceptualize, and illustrate the conflictual nature of culture in all its subtle, elusive and well disguised forms, along with our own role in these conflicts-for it is in these conflicts that culture in all its complexity, promise, and menace is both brought to life and put to death. Moreover, and perhaps less obviously to the residents of our comfortable academic environments, for the study of culture to become meaningful, and for its students to be equipped for the job, we believe it is important to step outside the boundaries of the secluded academic world of journals, with their stylized modes of writing and limited readership, and of detached and overly theorized classrooms. Rather, one must engage with and participate in the life under study. This should take place in ways that are more than merely "research, teaching and consulting" as commonly understood. The problem is not how to identify the ways to participate more fully in the life around us-they are abundantly documented and 
immediately available-but in the choice to do so and in the recognition of its vital importance. Finally, and perhaps most crucially, as teachers we believe that it is important to recognize, for ourselves and for our students, many of whom are headed for careers in the world of business organizations, that we were all born with innate ethnographic skills and are constantly try to making sense of the social and cultural world around us. Indeed, the skills we develop, hone, use or lose in the course of our lives-asking, listening, observing, interpreting, and theorizing-are the foundation of all action in all the domains of our lives. Fighting for culture thus means helping ourselves and our students rediscover and reconnect with these basic skills when teaching. The most important fight of all then seems to us to be an attempt to improve our students' ethnographic skills and promote their understanding and use of the concept of culture. This includes a critical awareness of its strengths and pitfalls, and an ability to form their own interpretations and theories, rather than parrot readymade ones, in all the locations relevant to their lives-and not only as employees, workers, and managers, but also as citizens, partners, parents, and friends. This we must do in the face of concerted and well organized efforts (with which we often wittingly or unwittingly collude) to discount, distort and undermine these abilities.

In conclusion, if one is necessary, we call then not for abandoning culture for its faults, but rather for fighting to promote it wherever it is in danger of succumbing to them-based on the recognition that the fault of the distortion of culture lies not in the concept, but in ourselves and in the way we choose to use it.

\section{Time for Culture}

Majken Schultz (Copenhagen Business School)

Organizational culture is one of the most paradoxical phenomena in organization studies, illustrating both the best and the worst of academia. However, it still has huge unexploited potential-a potential which is long overdue, for it is indeed time for culture to blend with current thinking in organization studies and take advantage of its rich conceptual heritage in a cultural revival. This, I want to suggest, should depart from a view of organizational culture as temporal process, although in this essay I will only address the treatment of culture in organization studies and realize that the development of the construct may have taken a different path in 
other fields, given its rich history outside of organization studies.

\section{The paradox of culture}

Organizational culture illustrates the best of academia in the way that the concept, drawing on anthropology and sociology, created a profound renewal in the understanding of organizations, when it entered the field in the mid-70s and was used thereafter. Serving as inspiration for both established and new generations of scholars, the concept of culture gained traction in ways that demonstrated academia's ability to explore new conceptual territories and to rethink established wisdom at the time. Culture gave importance to phenomena in organizational life, which previously had been overlooked or deemed irrelevant to organization scholars-from stories exchanged around the water-cooler to the subtleness of meaning creation. In addition, the concept of culture was early on embraced by practice which, in spite of numerous conceptual disagreements, showed the relevance of culture to people in and around organizations. But organizational culture also became a victim of the worst in academia in that paradigm wars, numerous elaborations of critical and postmodern perspectives, and the inability to create fruitful dialogue between them turned culture into a conceptual battlefield which proceeded to implode from the inside. At the same time, culture had peaked in the cycle of conceptual fashion, with the result that new generations of scholars have shown little interest in the construct.

This created a paradox that has been inherent in the development of the culture construct ever since, in that it is now both largely ignored in organization studies and embraced by practice and other disciplines. On the one hand, culture faded away during the 1990s and is now, at best, mentioned only in relation to the history of organization studies. In academic work thereafter, the concept has either been replaced by related constructs, such as organizational identity, where culture is reduced to an empirical question (e.g. Albert and Whetten, 1985. 265-66), or it is displaced from its organizational origin to an institutional level of analysis. Either way, the quest for culture in organizations studies has come to an end.

On the other hand, the insights provided by organizational culture have been picked up by a host of scholars working in other fields encouraged by the fact that culture has become an integrated part of practice, whether in management practices or the ways organizational actors understand life in organizations. In my opinion, a variety of new fields have embraced and further developed fundamental insights from culture: for example, studies of strategy-as-practice; the "signature processes" behind dynamic capabilities; the growing interest in materiality and artifacts in science-and technology studies; the focus on consumer cultures in marketing; and the concern with corporate branding in corporate communication studies. So, while organizational 
scholars for a decade ignored the culture construct, its inherent relevance and importance to all kinds of organizational processes have paved the way for its movement into other fields.

\section{The re-emergence of culture}

Recently, however, culture has started to re-emerge in organization studies. In their introduction to a special issue on "Cultural life in organizations," Weber and Dacin (2011) challenged a conception of culture associated with classical studies as inward-focused constraint, and argued for the need to develop a new view that sees culture as an externally oriented tool-kit-thereby reclaiming Swidler's early work. Similarly, in an extensive review of three decades of the study of culture in organization studies, culture becomes even more "agentic," as the authors recast 30 years of development of the culture field as an integrated framework based in values and tool-kits drawing on frames, categories and stories (Giorgi, Lockwood and Glynn, 2015). While these are important steps in setting culture free from what in management and organization studies had become a rather inward-looking, essenceoriented and pre-determined path, these reviews first and foremost suggest new analytical categories in the elaboration of cultural agency, by stressing how culture as a tool-kit, category, and/or frame can be mobilized and used by organizational actors.

Although such emphasis on cultural agency is a much needed reaction to the behavioural constraints imposed by culture, the risk is that the configurations that also constitute culture-whether it is the "webs of significance" coined by Geertz (1973: 5), or "patterns of basic assumptions" argued by Schein (1985/2010: 18)-are lost in the development of such a "neo-instrumental" view of culture. In my own opinion, the profound contribution of the culture concept is its ability to overcome established distinctions and explore the processes that connect them: for example, how culture both resides within ritualized tradition (the past) and serves as a resource for the construction of novelty (the future); how it emerges from life in organizations (internal), while being entangled with the outside world (external); and how it is both embedded in practices distributed among employees (at the bottom) and influenced by managerial actions (at the top). A cultural awakening in organization studies should be able to both acknowledge and go beyond such fundamental distinctions-an approach which, in my own opinion, is enabled by drawing upon the emerging process views on organizations.

As stated in several contributions, a process view is characterized by a pursuit to understand the inherent processes that constitute the continuous unfolding of the phenomena at hand: that is to say, organizational culture (e.g. Langley and Tsoukas, 2010; Hernes, 2014). Instead of searching for a fixed set of cultural categories that are seen to define the substance or essence of culture, a process view invites us to 
"acknowledge and absorb, rather than to reduce the complexity" (Schultz \& MacGuire, 2012: 6) inherent in the ongoing reconstructions of culture in organizations. In addition, a process view is based on temporality in that phenomena are always conceived of as constituted in time, while relating to others. This notion of a temporal process view, in particular, invites a new conceptualization of culture, or more accurately, enhances dimensions of organizational culture which was full of potential in its early development, but which somehow got lost in the academic paradigm wars, as well as in the reliance on simplified dichotomies in its practical application.

\section{Culture in time}

I want to suggest two areas where such a temporal process view may add to the further development of the culture concept in organization studies. The first concerns how a temporal view sees organizational culture as constituted in time by asking how cultural processes contribute to the continuous reconfiguration of the relations between past, present, and future in organizations. ${ }^{2}$ This suggests a reconceptualization of culture, where the focus is not on how culture develops across time so much as on how it is constructed in time.

The notion of time has been inherent in the conceptualization of culture, in the sense that culture is often constituted by its formation and transformation across time. For example, it has been conceived as consisting of those behavioural patterns, narratives and values that are passed on from one generation to the next, or as following the cycle of organizational life as it passes through stages of birth, midlife and maturity-seen most explicitly in the works of Schein (1985/2010). Here, culture is constrained and somewhat pre-determined by its assumed organizational role within a given organizational cycle, just as it imposes constraints on organizational actors by limiting the path in which a possible cultural future may develop. For example, actors operating within the early development of a culture find themselves looking into a future of cultural conflicts associated with growth and organizational diversification, whereas those in mid-life can expect a future of cultural inertia.

Others have conceived the development of culture across time in terms of shifts between periods of cultural stability and change. They have searched for explanations for what enables cultural change or, more often, for ways to overcome cultural resistance to change-thereby associating culture with references to a past treasured and maintained by organizational actors. Studies of culture have added complexity to such a period conception of culture across time by elaborating how often a culture changes (for example, by positing differences between fast-paced,

2 I here draw upon Hernes and Schultz (forthcoming). 
high tech cultures and slow-moving, bureaucratic cultures); or how long time it takes for actors to let go of the past and be assimilated into the new culture.

However, seen from a temporal perspective, such conceptions of culture externalize the notion of the future and the past from culture in the present, by implying that the future will happen and the past did happen independently of the present. In contrast, a temporal process view departs from the present only, and internalizes both future and past in the ongoing construction of culture by asserting that conceptions of what the future may become, and what the past might have been, are cultural constructions influenced and contextualized by the present. On the one hand, this provides cultural agency, in that actors are actively constructing their cultural future and past, and the relations between them, while being in the present. For example, actors make deliberate choices about which past cultural resources to evoke to support their envisioned future, while the unfolding of the future, in turn, influences what they conceive as cultural resources. On the other hand, a temporal process view imposes a temporal configuration on the construction of culture, which can never escape time, but is always taking place in time suspended between past and future. Any culture has layers upon layers of pasts and futures, which cannot be erased regardless of the intentions behind cultural transformation.

The ongoing construction of culture in time is found in (although it is not the only focus of) the study of a five-year transformational change process in the Carlsberg Group following a mega-merger in 2008 (Hatch, Schultz and Skov, 2015). The study suggests how the notion of the cultural past is reconstructed as change unfolds, and how the conception of the future is transformed from a post-merger integration of multiple nationally-based brewing cultures into an aspiration for a new, possible shared, future identity as a Fast-Moving-Consumer-Company sustained by a culture of professionalized efficiency. While actors are in the process of redefining their future, they reconstruct the past correspondingly-both through a process of stigmatizing aspects of the brewing heritage as inefficient, and by remembering forgotten cultural symbols and narratives, which are evoked and retold to enhance an image of how Carlsberg has always been dedicated to professional excellence. One such example is the story of how the founder, due to his dedication to scientific methods, was able to invent clean yeast and thereby provide a foundation for excellence and efficiency in the Carlsberg breweries. However, this unfolding construction of culture is riddled with tensions in that, for example, cultural resources originating from its brewing past are seen by top management as opposed to their push for efficiency, while several middle managers around the world see a brewing past as a potential shared point of reference in an even more dispersed globalized future (referring to growth by global acquisition in the brewing industry). 


\section{Co-created cultures}

The second area where a temporal process view may help development of the concept of culture in organization studies concerns how both external and internal stakeholders are active co-creators of culture-providing new sources for the development of culture, and forging relationships largely ignored by organizational culture studies. The notion of co-created culture draws on recent developments in brand and marketing studies (e.g. Mertz and Vargo, 2009), where scholars have shown the emergence of consumer-to-consumer relationships derived from a shared passion for specific experiences, such as driving old vintage Saab cars (Muñiz and O'Guinn, 2000), or sharing their dedication to construction play by using LEGO way into their adulthood (Antorini and Mûniz, 2013). Consumers may form more regular networks or communities, and so develop their own cultures underpinned by rituals, values and meaningful practices (e.g. Schau, Muñiz, and Arnould, 2009), which, in turn, enhance their motivation to actively engage with the organizations central to their network (such as the LEGO Company in relation to its communities of adult fans of LEGO). However, although studies in branding and marketing have gone into great detail in exploring the formation and development of cultural practices among consumers, they have shown less interest in the processes that connect community members with actors in the related organization (i.e. the LEGO Company).

By the same token, studies of organizational cultures have focused on relations inside the organization-whether they unfold between managers and employees, or among employees-and have paid less attention to relationships with external stakeholders, such as consumers. Studies of organizational culture have, of course, included the role and importance of external stakeholders in culture, but most often they have been conceived as a substantial category belonging to a different level of analysis, such as that of "institutionalized environment," thereby allowing scholars to show how organizational cultures imitate institutionalized environments; or that of "external environment," which demonstrates how organizational culture adapts to shifting external environments.

Following the insights from a process view that "'what is' has no existence apart from its relating to other things in time and space-what also is, what was, and what might be" (Schultz and McGuire, 2012: 6), I think we need a shift in focus from how cultures are influenced by, or adapt to, their external environments to the processes relating organizational actors to external stakeholders. In this way, we can conceive of stakeholders as engaging actors interacting with an organization, instead of as representations of analytical categories. The emergence of such entangled relations between actors inside and outside organizations has been discussed in areas of innovation and co-creation, where the relations between organizational actors and lead-users, or dedicated individuals, have proved to be of value both to the 
organizations involved (e.g. Merz and Vargo, 2009) and to the participating consumers/users (e.g. Ind, Inglesias and Schultz, 2013). However, actors are often conceived in terms of their individual competencies, experiences and emotions, while the impact of their belonging to a community or organizational cultures is underexplored. By the same token, the processes underpinning co-creation are often described in instrumental or value-creating terms (such as the four building blocks of co-creation by Prahalad and Ramaswany, 2004), rather than in terms of how they work as mechanisms for exchanges of cultural resources-such as symbols, stories and meaningful practices-between different culturally embedded actors outside (e.g. community cultures) and inside (organizational culture) the organization.

A significant example of co-creation processes between an organization and its consumers is found in the LEGO Group, where selforganized communities among adult fans of LEGO have had a profound impact on the innovation and revitalization of both LEGO products and their associated brand meaning (Antorini and Muñiz, 2013). Here, scholars suggest the importance of a cultural resonance within the organization in order to reap the full benefits of co-creation with users, as well as the risk of corporate systems overshadowing users' contributions. In a further development of the concept of culture, therefore, I want to suggest a stronger emphasis on how these ongoing relationships with users and/or consumers influence organizational culture itself, since the emergence of new forms of dialogue, exchanges of symbolic material, and the development of shared practices are all expected to impact cultural pockets with an organization. In addition, this raises questions of how such external relationships are distributed among organizational actors and how this, in turn, influences cultural processes in the organization itself.

Together these ideas propose a notion of organizational culture as becoming, as being always constructed in time through interwoven internal and external relationships. Conceiving culture in time opens up our research to studies of how actors influence the ongoing reconfigurations of the relationship between past and future, while being restricted by their culturally informed imagination for how the past and future may unfold. Conceiving culture as intertwined internal and external relationships paves the way for studies of how shifting actors participate in the ongoing construction of culture, each bringing their unique potential of cultural resources constructed in their own time.

\section{References}

Albert, S. and Whetten, D. A. (1985) Organizational identity. Research in Organizational Behaviour. 7: 263-295. 
Antorini, Y. M. and Muñiz, A. (2013) The benefits and challenges of collaborating with user communities. Research Technology Management. 56 (3): 21-28.

Geertz, C. (1973) The interpretation of cultures: Selected essays. New York, NY: Basic Books.

Hatch, M. J., Schultz, M. and Skov, A.M. (2015) Organizational identity and culture in the context of managed change: Transformation in the Carlsberg Group, 2009-2013. Academy of Management Discoveries. 1 (1): 56-88.

Giorgi, S., Lockwook, C. and Glynn, M. A. (2015) The many faces of culture: Making sense of 30 years of research on culture in organization studies. Academy of Management Annals (in press). London: Routledge.

Hernes, T. and Schultz, M. (forthcoming) Organizational culture and identity as process in time. In Langley, A. and Tsoukas, H (eds.), The Sage handbook of process organization studies. Thousand Oaks, California: Sage Publications.

Hernes, T. (2014) A process theory of organization. Oxford: Oxford University Press.

Ind, N., Iglesias, O. and Schultz, M. (2013) Building brands together: Emergence and outcome of co-creation: California Management Review. 55 (3): 5-29.

Langley, A. and Tsoukas, H. (2010) Introducing perspectives on process organization studies. In Langley, A. and Tsoukas, H. (eds.), Perspectives on process organization studies. Oxford, UK: Oxford University Press.

Merz, M. and Vargo, S. (2009) The evolving brand logic: A servicedominant logic perspective Journal of the Academy of Marketing Science. 37 (3): 328-344.

Muñiz, A. and O'Guinn, T. (2001) Brand community. Journal of Consumer Research. 27 (4): 412-432.

Prahalad, C. K. and Ramaswamy, V. (2004) The future of competition: Cocreating unique value with customers . Boston, MA: Harvard Business School Press.

Schein, E. (1985/2010) Organizational culture and leadership (4th edition). San Francisco: Jossey Bass.

Schau, H. J., Muñiz, A. and Arnould, E. J. (2009) How brand community practices create value. Journal of Marketing. 73 (5): 30-51.

Weber, C. \& Dacin, T. (2011) The cultural construction of organizational life: Introduction to special issue. Organization Science. 22 (2): 287-298. 


\section{On the Meaning(s) of Culture}

Tomoko Hamada Connolly (College of William and Mary)

McKinsey's survey of 1,420 global corporate executives in 2013 found that-despite women's aspiration, competence and performance-many CEOs were not yet convinced that a female manager had the long-term capacity to move up to the C-suite. The survey revealed that the career demand for "anytime, anywhere" availability of top executives imposed a severe penalty on female managers, and that they felt more confident about rising to positions on the board when the top's leadership style was compatible with their own leadership and communication styles. It concluded that "cultural factors" limited "gender diversity at the top" (McKinsey 2013).

With a new gender-diversity policy in hand, I have been promoting more female managers to the top echelon of a Japanese multinational which hired me as its first external board member in 2013. In order to devise an effective strategy for organizational transformation for genderequality, I have found recent findings in neuro-sciences quite useful. This essay will briefly summarize my ideas about culture, therefore, in the context of the field of corporate governance.

Anthropologists of organization in general agree that "culture" is an amalgam of historically derived meanings that include values, conventions, artifacts, norms, discursive practices, power-relations, and institutional habitus, which together constitute daily social realities for individual people. People constantly spin tales and retell stories. Stories are units of meanings that connect their images of past, present and future (Bruner 1986).

In recent years scholars in the neighbouring discipline of cognitive science have begun to reveal the actual neurological process about how the human brain processes socially-relevant, symbolic cognition and emotion. We now know that our brain learns by adding or removing connections, or by adding cells, and that new learning takes place through shifts in the strength of the connections of neurological firings, when connections are added or removed, or when new cells appear (Hagmann et al. 2010). The brain's neural wiring network is called the "connectome." What is significant is that, when a particular piece of new information from the environment adds more connectomic weights in different regions, this particular association of neural firings and their connectivity becomes more stable and less transitory. In other words, if we repeatedly "register" more and more relevant information from the 
environment, the brain's networked firings become more "routine and automatic." Here, repetition is the key: as we get repeatedly exposed to similar stimuli-responses over time, these webs of connectivity in our brain become more and more firmly created for long-term memorymaking. In this process called "priming," the brain progressively decouples deeper and more reflective "meaning creations" separate from mere "knee jerk" responses to environmental stimuli. This mechanism for reflective meaning-creation is considered to be a relatively resilient system due to its strong interconnectivity with multiple neuron activities in the brain. Here, social and biological factors work in concert in our learning, sense-making, and long-term memory retention (Turner \& Bruner 1986).

What is anthropologically significant is the fact that the more firmly primed, the more consistent the established schematic system of interconnectivity becomes. This way, the brain eventually develops complex connectivity webs of neural firings for moral and ethical judgment. The brain does this work by bringing in previously stored information and knowledge and by repeating and adjusting previous firing mechanisms (Rudebeck et al. 2008). In doing so, it deals with more context-based (value-oriented) "reasoning," together with such emotional responses as pride, honor, guilt, respect, embarrassment, worthiness, disillusionment, and disdain. These feelings are socially-induced emotive reactions that can be categorically differentiated from primary emotions such as raw anger, fear, and sexual impulse. With these new webs of reasoning schema, the brain can now deploy a kind of cognitive guideline or "cultural GPS" for future events. Environment is full of stimuli and if we see and register everything it will cause total chaos. When the brain gets repeatedly exposed to similar (meaningful) stimuli over time, then certain patterns of neuron connectivity become more primed, reinforced, and stabilized. Then the brain begins to guide us as to how and in what ways we "see" the future stimuli from the environment. The important point here is that the brain's cultural GPS guides us not to see certain stimuli while selectively guiding us to see other stimuli. Due to the fact that all human perceptions and experiences are mediated through this brain's priming mechanism, we tend to hold certain firing mechanisms for interpreting particular beliefs or behaviour as being more meaningful than others. When we encounter a new situation-such as a new business meeting, for example-our brain's cultural GPS promotes or demotes certain forms of behaviour in complex ways: for instance, as to when and how we should speak out, or remain silent in the meeting.

The relatively stable sets of integrated schema dictate not only "how we think," but also "how we feel." From a neuro-scientific standpoint, we can thus define culture in the following manner.

Please imagine a situation where two persons experience very similar life circumstances of mental schema creation, while receiving 
similar positive and/or negative reinforcements (such as awards and punishments). It is likely that they will develop a somewhat similar "how to think" and "how to feel" schematic connectivity over time. Just as important as their sharing of cognitive connectivity is the sharing of affective connectivity, because affect impacts these individuals' mutual feelings, trust, friendship, and camaraderie. It is predicted that these two people will develop the neural capacity to understand each other's learned perspectives and behavioural outcomes.

Although this argument does not take into consideration the stakeholders' biological or genetic make-ups, it is important to note that individuals who have similar priming experiences share some "circuits in the brain." Thus the experiences of the individual brain overlap with those of others to form collective aspects of group-level GPS. This means that the same brain areas in different stakeholders in a group are likely to get activated not only when they are involved in the first person perspective (I do/I feel), but also when they are concerned with the third person perspective (I "see" what he does and I know how he feels). It is quite likely that these individuals with particular cognitive circuits feel more comfortable with those who possess similar sets of neural connectivity because they are able to predict how the other tends to think/feel. If these persons share dense schematic connectivity with one another, it is easier for them to "put oneself in someone else's shoes," and to get the exact meaning of an issue almost instinctively without further articulation. Predictive knowledge may also enhance trust, respect, and momentum for collaboration, because "trust" is belief in a positive future outcome due to the perceived probability of the actions of others. In other words, if people can count on one another, they can collaborate with ease. Although never clearly stated in this way, this sense of trust is the base logic underpinnig some CEOs' desire to maintain the good old boys' tacit communication at the top.

The argument I present here helps us improve cultural strategies for organizational change. We now know that brain pathways can change as long as they are fired in certain scripted ways over an extended period of time, repeatedly, with positive or negative rewards and punishment. If this priming takes place in a scripted way, the brain neurons begin to be wired together. Thus new learning takes place and, as a result, the human mind and its cultural GPS become "retooled" for future stimuli.

Culture is a malleable medium for priming cognitive and emotive connectomes inside the human brain in order to see, register, memorize and act on certain environmental stimuli. Here, what and how culture lets us see is just as important as what we cannot see and register. Therefore, conversely speaking, culture is a malleable medium for priming cognitive emotive connectomes inside the brain not to see, nor to register, nor to memorize, nor to act on certain environmental stimuli. By examining culture this way, we will be able to move beyond the conventional 
exploration of "polyphonic, contested and often disharmonious, discursive interactions among actors," and to ponder what is happening in individual brains. By viewing organization as cognitive and emotive maps, we will be able to pinpoint "mental" overlaps, gaps, stresses, stretches, and, most importantly, those not-yet visible connectomic connections among stakeholders' activities.

When enough people think and feel their shared sense of purpose, retooling of connectomes for organizational change becomes possible. The highly-entrenched connectivity among core stakeholders such as board members tends to spawn a monolithic or dominant "way to see" and "way to feel." Since they share multiple decades of socialization and professionalization, and since they communicate with one another almost daily, their brains are highly primed to the existing ways of "seeing" and "not seeing."

What is more, it is not just the brain that handles this task of registering stimuli. We know that the microbes inside our "guts" may have crucial roles for our "gut feelings." Although sciences have not revealed the mechanism completely, it is an exciting new area for anthropologists to think that what we consume inside our colons may have much to do with our cultural orientation. Equipped with the abovementioned neuro-sociological construct of culture, we can see that a new strategy for organizational change is now taking shape.

Culture does not exist without people. One role for an anthropologist, then, is to explicate the linkage between the individual agency's neural activity for sense-making, socio-political structure, and institutional dynamics for collective transformation of our community.

\section{References}

Bruner, Edward. M. 1986 “ Experience and its expressions.” In Victor W. Turner and Edward M. Bruner (eds.), The Anthropology of Experience, Champaign, Il: University of Illinois Press, pp.3-32.

Hagmann, Patrick, Sporns, O.,' Madan, N., Cammoun, L., Pienaar, R., Wedeen, V. J., Meuli, R., Thiran, J-P. and P. E. Grant 2010 “White matter maturation reshapes structural connectivity in the late developing human brain." PNAS (the Proceedings of the National Academy of Sciences of the United States of America) Vol. 107, No. 44: 19067-72. http://www.pnas.org/content/107/44/19067.full

McKinsey \& Company 2013 Women Matter: Report 2013. Gender Diversity in Top Management. http://www.mckinsey.com/Features/Women Matter

Rudebeck, Peter H., Behrens, T. E., Kennerley, S. W., Baxter, M. G., Buckley, M. J., Walton, M. E. and M. F. S. Rushworth 2008 "Frontal cortex 
subregions play distinct roles in choices between actions and stimuli." Journal of Neuroscience. Vol. 28, No. 51: 13775-85.

Turner, Victor W. and Edward Bruner M. (eds.), 1986 The Anthropology of Experience, Champaign IL: University of Illinois Press.

\section{Culture and keywords in organisations: a case of continual contestation}

Susan Wright (Aarhus University)

I approach "organisational culture" as a continual contest over keywords that are never capable of a closed meaning or final resolution. Central to this approach is, first, analysing how managers, or those aspiring to leadership, try to assert the right and power to shape an organisation's central concepts-not least the concept of the organisation's "culture" itself. Often the meaning of a keyword does not change alone, but its previous associations with other words are broken up, and its meaning is reformed through linkage to new words, in what I call a new "semantic cluster." This contest over the power to define keywords and assemble new semantic clusters is analysed to see what kind of organisation the leaders are trying to create. The second question is whether and how other participants in the organisation are unpacking this semantic cluster and exposing the meanings that are being asserted for these words? And third, are they able to put forward alternative meanings for these words, or a different semantic cluster around the keyword, in order to project an alternative vision of the organisation and its management? Who in this contest has the skill and power to make their definition of keywords "stick" (Thompson 1984) and become instantiated in institutional practices?

This approach to organisational culture derives from the way "culture" was being discussed in anthropology and cultural studies in the 1980 s and 1990s, and is in contrast to the way organisational studies focused on culture at that time (Wright 1994, 2005). In organisational studies, following Peters and Waterman (1982), writers came to expect that all employees of a private company would endorse certain core values and would associate such values with the organisation's "culture." They often looked to anthropology to legitimise their use of this concept. In doing so, they were appealing to an "old" idea of culture from which anthropologists were fast distancing themselves (Wright 1998). This is 
the idea that a "people" or society has one shared and consensual set of values that is homogeneously spread among all the members and underpins all aspects of the way they organise their life. When this idea of culture was adopted as a management tool, the challenge for managers was to establish a set of core values for their organisation that would cohere all its members together, from the CEO to the doorman, and underpin the way they all did their work.

Initially this unitary idea of culture had enabled anthropologists in the 1920s to make the radical argument that it was not just colonial powers which had culture; every "people" had a culture and all cultures were valid, if different, and should be respected. By the 1980s, this idea had lost its radical edge. This idea of culture had become a tool of government: spaces to be governed were divided into "cultures," the supposedly static and homogeneous characteristics of each culture were "known" and even listed, and practices of government and methods of control were developed accordingly. Anthropologists critiqued their own practice and realised that their depictions of a people's culture had often been through fieldworkers" using dominant men as their "chief informants." Instead of lending authenticity to dominant voices, there was a growing call within anthropology to "study up" and explore how people's lives were shaped or influenced by systems of bureaucratic government or new forms of imperialism (Nader 1969, Gough 1968). An article by Talal Asad (1979) was especially influential in making anthropologists realise that the unitary view of culture is a representation of a dominant ideology; that people positioned differently in the society might have very different ideas; and that culture is always changing-it only seems homogeneous and static in moments of hegemony.

At the same time, cultural studies developed a repertoire of new concepts and methods for studying how people in their everyday lives interacted with processes of governing. Central to their approach was the idea that culture is contested. Stuart Hall at the Birmingham Centre for Contemporary Cultural Studies (CCCS) drew on Gramsci, among other European political philosophers, to examine the Thatcher years in the UK as a contested process of asserting hegemony (Hall 1988). Strongly informed by CCCS, the core cultural studies course at Sussex University posed, as the central question to ask of any situation: "Who has the power to define what, for whom, with what material consequences?" Raymond Williams at Cambridge showed that central to any process of social transformation is contestation over the meaning of "keywords" (1976). He drew on Gallie's much earlier insight that some words are central to debates over how to conceptualise and organise society and polity. These words never have a closed and final meaning; they are "essentially contested concepts" (Gallie 1956). Williams showed how words such a "culture" accumulate a history of meanings and in emergent situations, they acquire new meanings, existing meanings are stretched, or old meanings come again to the fore. Street (1993) brought these strands of 
thinking from anthropology and cultural studies together by declaring "Culture is a verb." That is, he argued against anthropology's old nominative definition of the culture of a people and argued instead that culture is a "doing word," constantly shaping and changing in a process of social contestation.

How can these ideas of culture be used to analyse the significance of current contestations over the keyword "freedom" in U.S. universities, as an example of organisations that are in a process of transformation? U.S. universities were once famously depicted as systems where departments and other units were only "loosely coupled" to the central management (Weick 1976). In the last 20 years presidents and chancellors have been trying to turn universities into top-down managed and coherent organisations. They model their idea of a university as an organisation on an image of a private sector business with its "corporate culture" asserting hegemonic control and apparent consensus among employees (Kunda 1992, Casey 1995). To make "culture" into a tool of management, they need to appropriate its keywords, and especially the "bedrock" of university culture: academic freedom.

Analysing this process through the perspective of "new" ideas of culture in anthropology and cultural studies, the first step is to question how presidents and chancellors are trying to redefine the meaning of "freedom," often by breaking up its previous associations with other words and linking it to new words in a new "semantic cluster." The second question is whether and how academics and students are exposing the meanings that presidents and chancellors are asserting for these words? And third, are academics and students able not just to contest the presidents" and chancellors" ideas of freedom but to put forward alternative meanings for these words which convey a different vision of the organisation and management of the university? Finally, whose ideas gain such dominance that they become authoritative by being incorporated into the university's procedures and practices and sometimes become so widely accepted and taken-for-granted that they gain the hegemonic status of the new normal? Where there is access for ethnographic research these questions can be followed through events and through time to analyse how a process of transformation of the key cultural concepts comes about - a research strategy Wright and Reinhold (2011) call "studying through." However, some of this process can be gleaned by asking these questions of publicly available documents, as is the cases below.

In 2014-15, university chancellors and presidents in the U.S. issued a spate of open letters to their faculty arguing that academic freedom had to be exercised with "civility" in order to make the campus "safe" for all students, academics and staff. This set off a debate about whether it was just chancellors and presidents who had the power to define university "freedom," or whether academics and students also had the right to 
participate in defining and practicing "freedom" as a concept that is central to university culture. Ever since the students" Free Speech Movement on the campus of the University of California, Berkeley in 1964-5, U.S. universities have been a prime site for Americans to exercise their First Amendment protection of speech, both civil and uncivil. These civil rights have been reinforced and enhanced by agreements on academic freedom (regarding research and teaching), security of tenure against dismissal for political reasons, and shared governance between faculty and university administration (in which the former are involved in decisions that rest on academic evaluation, including hiring, tenure and promotion). Together these are the bedrock of "freedom" as the core principle of the U.S. university. University faculty and students are to use this freedom to fulfil their responsibility to society: it is their role to identify injustices, critique conventional wisdoms, and question prevailing ways of doing things in their own disciplines, in their society and in the world, and to propose alternatives. What happens to this concept of academic freedom if presidents and chancellors try to assert the power to define it and associate it with "civility" and "safety"?

One example of the language linking "freedom" to "civility" and "security" is found in the statement that Chancellor Dirks (2014) made to celebrate the 50th anniversary of the Free Speech Movement at the University of California Berkeley:

“... Free speech is the cornerstone of our nation and society ... For a half century now, our University has been a symbol and embodiment of that ideal... [but] when issues are inherently divisive, controversial and capable of arousing strong feelings, the commitment to free speech and expression can lead to division and divisiveness that undermine a community's foundation. ... Specifically, we can only exercise our right to free speech insofar as we feel safe and respected in doing so, and this in turn requires that people treat each other with civility... Insofar as we wish to honor the ideal of Free Speech, therefore, we should do so by exercising it graciously."

This sounds very reasonable and many academics also dislike the gratuitous insults and nastiness that sometimes oust attempts at academic discussion, but why is a chancellor telling his faculty this? A faculty member and blogger, Michael Meranze (2014), pointed out that "civility" had been deployed to demonise students in the 1960s" Freedom of Speech Movement as "barbarians at the gates of proper university discourse and debate." Meranze surmises that the chancellor, as a scholar of Indian history who showed how a long period of English colonial rule had been justified under the terms of liberal civility, surely realises that his repetitive invocation of "civil" and "civility" and his paternalistic 
instruction in "gracious" manners does not facilitate open debate. Rather, by equating safety with a "crimped vision of civility" and anodyne debate, the upper administrators have employed the language of civility to override the outcome of the academic process and to intrude into the independence of academic decisions (ibid.).

Calls for "civility" were also made the chancellor at Penn State when there were deep disagreements among alumni, faculty and students over controversial management actions that followed their deputy football coach being found guilty of 45 counts of child sexual abuse. Whereas the football team had been a focus of college unity and sense of community, now it was divisive. On the eve of the first home match of the season, the new President (Barron 2014a and b) published a letter, backed by the entire leadership of 83 people, and he made a YouTube video appealing to faculty and students to restore the "core values" of "respect and civility" on which an academic community is based. These core values may be indisputable, but those contesting the decisions of the university leaders felt civility was being mobilised to close off debate. This language, linking "freedom" to "civility" and "security" is found in other instances when questionable administrative decisions have provoked divisions among the faculty, and when leaders are trying to assert a right to top-down management of what others maintain is an academic community with shared governance. For example, in a blog, the chancellor of the University of Illinois at Urbana-Champaign explained to colleagues why the Board of Trustees had rescinded a tenure-job offer just prior to the professor starting teaching (Wise 2014). Steven Salaita is a PalestinianAmerican who researches and teaches Native American history. In a private capacity, he tweeted in strong terms about the Israeli bombing of Gaza. The chancellor explained that she is absolutely committed to the "bedrock principle" of academic freedom, but that it is her responsibility to ensure that differing points of view are "discussed in and outside the classroom in a scholarly, civil and productive manner" (ibid.). She is committed to "creating a welcoming environment for faculty and students alike to explore the most difficult, contentious and complex issues facing our society today," but:

"What we cannot and will not tolerate at the University of Illinois are personal and disrespectful words or actions that demean and abuse either viewpoints themselves or those who express them....

"A Jewish student, a Palestinian student, or any student of any faith or background must feel confident that personal views can be expressed and that philosophical disagreements with a faculty member can be debated in a civil, thoughtful and mutually respectful manner" (ibid.).

Three hundred faculty responded in an open letter (Weblog 2014) 
contesting the chancellor's definition of academic freedom. They argued, first, that shared governance was also a bedrock of academic freedom. Professor Salaita had been selected for the job on academic grounds and by following due process from the department through the echelons of the university. By retracting Salaita's job offer just before he started work and a few days after his Gaza tweets with no apparent faculty consultation, "the Chancellor violated the university's established procedures and principles of shared governance." Second, they defended the right of academics, as citizens, to exercise freedom of speech. They argued that "a faculty member's extramural political opinions have no place in the evaluation of that individual's scholarship, teaching, or collegiality" and "Salaita's record of highly reputed scholarship and teaching is nowhere in dispute." They called the decision "a dangerous attack on academic freedom which will exert a chilling effect on political speech throughout our campus."

Third, they asserted that it was they who were defending the integrity of the university. If, as it was reported, the decision was a hurried response to "particular donors" and a "campaign by off-campus political groups to tarnish Salaita as an anti-Semitic critic of Israel," the University of Illinois appeared to have disregarded its own protocols for handling concerns from the public. This meant "the integrity and reputation of our campus has suffered a terrible blow." They were "concerned that the revocation of Salaita's position might embolden intolerant forces in the community and on campus. These actions have already created a climate of fear and stoked an already tense racial climate" (ibid.). Fourth they exposed and critiqued the chancellor's association of academic freedom with "civility" and "safety." They recognised the importance of civil discourse, but it was "troubling" that the Chancellor and Board have described this decision as a victory for civility, academic excellence, and "robust debate." Acting

"in the name of promoting student "comfort" or assuring a "welcoming environment" is, in effect, to license political censorship and arbitrary decree. It unacceptably endows the Chancellor and Board with authority to monitor, evaluate, and punish faculty members for the way they exercise their rights and duties as citizens" (ibid.).

In their letter, the faculty effectively challenged the chancellor's definition of "freedom" and the link she claimed between freedom, citizenship, civility and comfort; and they asserted the right to participate in shaping their organisation through their version of "freedom," by defending the university's public reputation, its heated though reasoned debates, internal diversity and shared governance. But the faculty campaign, backed by letters from several professional associations (AAA 2014, AHA 2014, MESA 2014), did not reverse the decision. 
To sum up the general points arising from these examples, first, it is not an unusual tactic for people in senior positions to publish statements in which they claim the right to define a word that is key to the culture of their organisation or community and to translate that into an associated set of practices for their institution. Home Office ministers in the U.K. have periodically issued statements claiming the right to define "British culture" at moments when their hegemony is threatened. Notably, following the Ayatollah Khomeini's fatwa against the author Salman Rushdie, the Home Office minister sent an open letter to British Muslims explaining how they should abide by the core institutions of British culture (Asad 1993). More recently, in the face of scandals in some Muslim schools, the Department of Education (2014) issued advice to all heads of schools and teachers that translated their legal obligation to "promote the spiritual, moral, cultural, mental and physical development of pupils" into "actively promoting British values."

Second, the contest is focused on warm words that all in the organisation or community hold dear and that cannot be opposed. Nobody in the university can advocate the opposite of "freedom," nor could they be outright opposed to freedom's new subalterns, security, civility and democracy. The contest has to be conducted inside these words. The challenge is to uncover the ways particularly positioned people are making subtle shifts in the meaning of the keyword itself and through a new cluster of associated words, and to expose the implications for the "bedrock" values of the institution.

A third common feature is that the contest over the power to define keywords has material consequences and is intimately linked to changes in institutional practices. In the above examples, the leadership is advancing "civility" to close down discussion of its own controversial actions, and diminish the role of academics and students in shared governance and political participation in the shaping of "their" institution. At the same time, leaders are claiming their universities depend for their vibrancy on being "communities"-just ones that they themselves define. By envisaging organisational culture as continually contested rather than as an a priori unity, "culture" becomes a powerful analytical tool for investigating such moments of organisational change.

\section{References}

Asad, Talal 1979 "Anthropology and the analysis of ideology." Man: Journal of the Royal Anthropological Institute, 14(4): 607-27.

Asad, Talal 1993 "Multiculturalism and British identity in the wake of the Rushdie affair." In his Genealogies of Religion. Baltimore: Hopkins University Press, pp. 239-268. 
Casey, Catherine 1995 Work, Self, and Society : After Industrialism. London and New York: Routledge.

Gallie, W. B. 1956 "Essentially contested concepts." Proceedings of the Aristotelian Society, 56: 167-98.

Gough, Kathleen 1968 Anthropology and Imperialism. Boston, Mass.: New England Free Press.

Hall, Stuart 1988 The Hard Road to Renewal. Thatcherism and the Crisis of the Left. London: Verso.

Kunda, Gideon. 1992. Engineering Culture: Control and Commitment in a High-Tech Corporation. Philadelphia, PA: Temple University Press.

Nader, Laura 1969 "Up the anthropologist : Perspectives gained from studying up." In Dell Hymes (ed.), Reinventing Anthropology. New York: Random House.

Peter, Tom and Waterman, Robert H. 1982 In Search of Excellence. New York: Harper and Row.

Street, Brian V. 1993 "Culture is a verb: Anthropological aspects of language and cultural process." In Graddol, D., Thompson, L. and M. Byram (eds), Language and Culture. Clevedon, UK: BAAL in association with Multilingual Matters. pp. 23-43.

Thompson, John B. 1984 Studies in the Theory of Ideology. Cambridge: Polity.

Weick, Karl 1976 "Educational organizations as loosely coupled systems." Administrative Science Quarterly, 21: 1-9 (part 1).

Williams, Raymond 1976 Keywords. A Vocabulary of Culture and Society. London: Fontana Press.

Wright, Susan 1994 "'Culture' in anthropology and organizational studies." In S. Wright (ed.), Anthropology of Organizations London: Routledge, pp. 1-34.

Wright, Susan 1998 "Politicisation of culture." Anthropology Today, 14(1): $7-15$.

Wright, Susan 2005, "Processes of social transformation: An anthropology of English higher education policy.” In John Krejsler, Niels Kryger, and Jon Milner (eds), Pædagogisk antropologi-Et fag i tilblivelse. Copenhagen: Danmarks Pædagogiske Universitets Forlag.

Wright, Susan and Reinhold, Sue 2011 "'Studying through': a strategy for studying political transformations. Or sex, lies and British politics." In Cris Shore, Susan Wright and Davide Peró (eds), Policy Worlds: Anthropology and the Anatomy of Contemporary Power, EASA Series. Oxford: Berghahn, pp. 86-104. 


\section{Documentary sources}

American Anthropological Association 2014 "Letter from President and President-elect to Dr. Phyllis Wise, Chancellor University of Illinois Urbana-Champaign." 4 September.

https://aaanet.files.wordpress.com/2014/09/140904aaa_officers_ltr_wise_re_salaita.pdf (Accessed 8 April 2015)

American Historical Association 2014 "Letter of Concern to University of Illinois Chancellor Regarding Salaita Case (2014)." From the President, President-elect and Immediate Past President, 31 August.

https://www.historians.org/news-and-advocacy/statements-andresolutions-of-support-and-protest/letter-of-concern-to-university-ofillinois-chancellor-regarding-salaita-case (Accessed 8 April 2015)

Barron, Eric J., President of Penn State University 2014a "A message from the leadership at Penn State." 5 September http://news.psu.edu/story/325057/2014/09/05/message-leadershippenn-state (Accessed 8 April 2015).

Barron, Eric J., President of Penn State University 2014b “Civility and respect." You Tube video, 4 September, https://www.youtube.com/watch?v=Nzt3WCSuVc8 (Accessed 8 April 2015).

Dirks, Nicholas, Chancellor of University of California Berkeley 2014 "From the Free Speech Movement to the Reign of Civility." An open letter to faculty, staff and students. 5 September.

http://reclaimuc.blogspot.dk/2014/09/from-free-speech-movement-toreign-of.html (Accessed 9 April 2015).

Meranze, Michael 2014 "The order of civility." Remaking the University blog, 7 September. http://utotherescue.blogspot.dk/2014/09/the-orderof-civility.html (Accessed 7 April 2015).

Meranze, Michael 2015 "Crisis over expression continues at UC Irvine." Remaking the University blog, 11 March.

http://utotherescue.blogspot.dk/2015/03/crisis-over-expressioncontinues-at-uc.html (Accessed 9 April 2015).

Middle East Studies Association 2014 "Letter to Dr. Phyllis M. Wise, Chancellor on behalf of the Committee on Academic Freedom of the Middle East Studies Association of North America." 11 August. http://mesana.org/committees/academic-freedom/intervention/lettersnorth-america.html\#US20140811 (Accessed 8 April 2015).

Weblog for faculty of the University of Illinois 2014 "Academic Freedom and Justice at the University of Illinois. Open Letter to Chancellor Phyllis Wise, President Robert Easter, and the University of Illinois Board of Trustees." 30 October. http://uiucfaculty.blogspot.dk/2014/08/openletter-to-chancellor-phyllis-wise.html (Accessed 8 April 2015).

Wise, Phyllis M., Chancellor of University of Illinois at Urbana-Champaign 
2014 "The Principles on Which We Stand." Chancellor's Blog 22 August. https://illinois.edu/blog/view/1109/115906 (Accessed 8 April 2015).

\section{What "culture" can do for business anthropology}

Gert Jan Hofstede (Wageningen University)

On my $58^{\text {th }}$ birthday, I received a friendly email message from Jakob Krause-Jensen asking me for a "short and informal opinion piece about 'culture."' Jakob explained: "It should be about the way you've used it and the role it has played in your research; whether you think it's a meaningful analytical concept or whether, as many anthropologists seem to believe, we should discard it." You see, I am used to being invited by companies, universities, governments, cross-cultural psychologists-but rarely by sociologists, let alone anthropologists. Here was an anthropologist inviting me, knowing full well that I was not in-group, for my deviant opinion. I decided it was a birthday present and gladly accepted.

Of course, I have found "culture" an analytically most useful concept. As a researcher, I consider myself an explorer, a "forager in intellectual space" (a phrase from Yoshi Kashima, a psychologist from Melbourne) who wants to chart new territory. In my case my dream is to achieve a helicopter perspective on human behaviour that is of practical use. An explorer needs tools: a compass, a Swiss army knife, some good rope. These tools have no need to be "true," but they need to be useful in the real world: to allow me to cut branches, climb trees, achieve perspective and find my way. As such, culture has served me very well.

Besides being an explorer I am also, by education, a biologist. When I started in 1976 the choice was between levels of aggregation: cell, individual, population. DNA had just been discovered, and the brain hype had not yet begun. Anyway, I chose population, focusing on animal behaviour and plant ecology, but I never forgot that reality is too complex for us to grasp it all using one level of analysis. After my studies, the job market drove me to computer programming. The advent of the World Wide Web in the mid-nineties brought organizational life back within the scope of Information Systems professionals, and since then I have happily been a biologist of human social behaviour.

I read the second issue of the JBA (Moeran, 2012) with some care and considerable pleasure. If my understanding is good, here is a group 
that is concerned with its delineation and raison d'être, that values style, erudition, examples from practice, and inclusive democracy. It hesitates to claim truth. Its mission is something like "describe organizational life as it really is, and make the members of the organization see this." That's an aim close to my own one, zoomed in on life in organizations.

Please forgive me for digressing into a little argument at this point. An out-group mentioned by some-for instance, Eric Arnould and Richard Swedberg-with derogatory undertones is constituted by economists. The latter writes "By closely observing what actually happens, rather than engaging in theory-driven research of the type that economists tend to engage in..." (p. 283). While I sympathize with the feeling that quite a few economists tend to disregard social reality, I highlight the remark about theory, because you might be throwing out the baby with the bath water. I have had the experience that sociologists have criticized my work for being theory-driven. What is wrong with that, if the theory can help people make sense of things? Nothing is more practical than a good theory; it is dogmatic use of poor theory that we should avoid.

In what follows I'll try to argue which theories, including culture, have served me well and could serve business anthropologists. I shall cut corners in the most dreadful way in so doing, for which I ask your tolerance. In particular, I shall not summarise any theory on culture, nor discuss various possible meanings of the word. I'm adding references that fill some of the gaps.

\section{Levels of analysis}

Social simulation has been my focus recently. This implies inventing models that re-create aspects of social life in virtual humans, and it therefore leans heavily on theory. What levels of analysis do I think are crucial to my grand aim? These are the individual, the group, and humanity as a whole. Of these, the last is the most important. It is about regularities that apply to everyone.

\section{Everyone}

As a biologist, I consider myself and my conspecifics to be social mammals living in a world of group-based status relationships, with power as a mechanism for when things go wrong. My most helpful tool in this area is Theodore Kemper's status-power theory (Kemper, 2011). Because I believe this theory to be useful for business anthropologists and too little known, I shall give a succinct summary of its argument here. Kemper, a sociologist based in New York, posits in a brilliant book that the essence of our social lives is to confer, and to claim, status. "Status" here can mean attention, love, respect, honour, proficiency, and so on and so forth. We wish for nothing better than to confer status upon the worthy. Whatever 
substantial aim anyone tries to achieve, says Kemper, there must be a status-power impact to it. For instance, when Jacob invited me to write this paper he conferred a lot of status upon me: it was a flattering request. The fact that I consented is a status claim on my part: I claim to be interesting and instructive to the community of business anthropologists. Whether this community grants my status claim remains to be seen; I hope to be found worthy.

In Kemper's language, power enters the arena when this game of mutual status conferral and granted claims fails, which it does as soon as claims outweigh conferrals. A refusal to publish a paper constitutes a power move by an editor. Power can be institutionalized. If a community has granted certain powers to some of its members, Kemper calls this authority. Power use always comes at the price of creating resentment, though this can be much mitigated in the case of authority. Hence it always pays to be nice about things, and to disguise status claims and power moves as status conferrals.

\section{Groups}

In outlining his theory, Kemper adds that people play their status-power game in groups, not just as individuals. They like to be with groups that confer status on them, and try to get away from groups that do not. They also play the game at a group level, trying to claim status for the groups to which they commit, and downplaying the status of other groups. Grouplevel phenomena of this kind have been extensively tested by social psychologists, well summarized in the work of the English psychologist, Rupert Brown (Brown, 2000).

My most useful tool regarding groups is "culture." Culture, as I use the word, constitutes the unwritten rules of the social game (G. Hofstede, Hofstede, \& Minkov, 2010). Culture is in our nature: that is, all people share the capacity for culture. Culture in this sense fits seamlessly with Kemper's model. This is not the place to enter into detail (but see G. J. Hofstede, 2013). Let me indicate that culture is about the social unit that is worthy of status conferrals, the desirable degree of symmetry of status relationships across ages, genders and roles, the degree to which power use is acceptable, the rigidity of status-power rules, and similar broad questions that make up the basic fabric of societies. We are socialized into our culture from birth, in inescapable ways. In my father's famous phrase, culture constitutes the "software of our minds."

\section{Individuals}

So far, I have not said anything about individuals, and yet it is individuals who carry the behavioural tendencies described by Kemper, Hofstede, Brown, and thousands of other scholars. This only seems to be a paradox. 
Certainly, every individual, every dyad, every group, every work situation, is unique. Still, it is possible to make statements at higher levels of aggregation that have empirical validity and predictive power: for example, about an organization or country. It is not because every day has its own weather that we cannot speak of a country's climate and talk sense.

This is where I believe that anthropologists tend to differ from biologists. Anthropologists like to zoom in and see differences, where biologists look for regularities. The former wish to know the weather, the latter the climate. These can be complementary endeavours. For instance, using interviews over an eleven-year interval, a recent case study of a cross-cultural merger discovered that, while dimensional theory predicted what kinds of problems could occur, social constructivist theory found out whether they were likely to occur in this particular case (Lee, Kim, \& Park, 2014). The fact that these authors found merit in both approaches, by the way, testifies to a "Swiss army knife attitude" towards theory. I like that.

\section{Institutions}

One thing I'd like to add here, although it is not a level of analysis, is the fact that we humans are so good at what biologists call niche construction. We do this not only in the physical world, which we are altering at a staggering scale, but also in the symbolic world. We construct reputations and myths. We admire heroes. We engage in rituals and spend our lives doing things in the name of institutions. Some or other species of social animals do most of these, but we have refined language and added script and money. A theory that helps me here is US philosopher John Searle's "social construction of reality" (Searle, 1995). Yet I do not believe that all this impressive institutional activity makes us any less biological, or diminishes in any way our basic nature as a social mammal living in groups with intensive fission-fusion activity. We have merely added a trick or two to the bag used by other mammals.

\section{Summing up}

To conclude the tour of levels of analysis: I believe culture to be right at the centre of our lives as social mammals. Culture makes up the unwritten rules that keep us from having to fight over social and physical resources all the time. It allows us to stay away from the use of power and to successfully play the status game. Any group of people put together for any amount of time will develop culture. Getting to know that culture is a central endeavour for business anthropologists, and a difficult one, because of the tendency of both the status-power game and its cultural variations to be hidden from the consciousness of its players. 


\section{Culture in my research}

How have I myself used the concept of culture? This takes me back to Lausanne, Switzerland, in the early seventies, where I had a wonderful time at the college de l'Elysée. Although l'd learned French in the Netherlands, nothing had prepared me for the social life in my new country. On the one hand, there were discussion groups in which teachers and pupils sat together in the most egalitarian way. On the other hand, there were adversarial relations, including the pupil-made weekly Zéro de conduit; the ritualized wrestling sport lutte Suisse only accessible to boys; the strange fact that boys had no first names and girls no family names; and a sit-down strike ended by a school director brandishing a whip. Such a man would have been considered mentally deranged back in the Netherlands. These and other events were discussed at home, and my dad used the burgeoning "dimensions of culture" he was discovering in his research material to make sense of differences between the Netherlands and Suisse Romande.

I remembered these lessons twenty-odd years later when, as a computer scientist, I became involved in a project about the "international office of the future." This led to a phase in which I created simulation games about information management in international settings, using my father's dimensions as scripting devices: so-called synthetic cultures (G. J. Hofstede \& Pedersen, 1999; G. J. Hofstede, Pedersen, \& Hofstede, 2002). These games found wide application. They showed among others that the same explicit game rules, when played by people from a different culture, lead to predictably different game dynamics (G. J. Hofstede \& Tipton Murff, 2011). My next research phase involved transparency and trust in networks of organizations, centred on supply chains. This led to some publications that show how building a supply chain, rather than another form of governance, is much more likely in some cultures than in others (G. J. Hofstede, Spaans, Schepers, Trienekens, \& Beulens, 2004).

During the past decade I became involved in social simulation, which has the aim to reproduce aspects of human social behaviour. The trick here is that one has to teach one's virtual humans every little thing. Unlike real people in a simulation game, virtual "agents" have no innate drives or culture. So in order to program them, one really has to get to the bottom of the matter. Kemper's and Hofstede's theory so far seem to do the trick pretty well for me (G. J. Hofstede, Dignum, Prada, Student, \& Vanhée, 2015), although other theories can work too (see, for example, Heise, 2013). A crucial, particularly thorny aspect of social simulations is that "we do not intend the consequences of our actions" (Italian psychologist Cristiano Castelfranchi): we collectively self-organize into patterns that nobody ever intended. Social simulation models allow 
investigating these emergent patterns.

\section{Concluding remarks}

Culture has been useful to me in the sense that I have helped many practitioners make more sense of their organizational lives using culture. Do I recommend "culture" for business anthropologists-or should I say for other business anthropologists? That depends on the level of analysis they seek. A researcher could zoom in on one case and be descriptive about it, without using any preconceived theoretical notions other than those embedded in language. This can yield enlightening case accounts.

Be this as it may, Brian Moeran is very explicit in stating that "we must be comparative" (Moeran, 2012, p. 296). He means this in the sense of comparing either across organizations, or across societies, or both. If the community accepts this, then decidedly the two distinct concepts of culture in the Hofstede perspective can be useful. I refer, first, to organizational culture, learned on entry and centred on the shared meaning of practices in organizations; and second, to national culture, learned from birth and centred on shared unwritten rules of the social game. Depending on what one is comparing, other levels of culture might also be useful: for example, gender, age cohort, profession, ethnicity. To repeat: theories are best used as tools. A researcher can try if s/he can to do the job of helping compare cases; if so, they are worth using. The track record of the national culture dimensions in this regard is not bad. They tend to explain around 35 per cent of the variance of sundry phenomena that were studied using them (Kirkman, Lowe, \& Gibson, 2006; Taras, Kirkman, \& Steel, 2010) . While this is impressive, the good news is that it still leaves room for a lot of explorative work on the part of scholars, whether or not they sport the beautiful name of business anthropologists. Though this be madness, there is method in it.

\section{References}

Brown, R. (2000). Group Processes: Dynamics within and between groups (2nd ed.). Malden, MA: Blackwell.

Heise, D. R. (2013). Modeling Interactions in Small Groups. Social Psychology Quarterly, 76(1), 52-72. doi: 10.1177/0190272512467654

Hofstede, G., Hofstede, G. J., \& Minkov, M. (2010). Cultures and Organizations, Software of the Mind (3rd ed.). New York: McGraw Hill.

Hofstede, G. J. (2013). Theory in social simulation: Status-Power theory, national culture and emergence of the glass ceiling. Paper presented at the AISB 2013 Social.Path, Exeter.

Hofstede, G. J., Dignum, F., Prada, R., Student, J., \& Vanhée, L. (2015). 
Gender differences: the role of nature, nurture, social identity and selforganization. In F. Grimaldo \& E. Norling (Eds.), MABS 2014 (Vol. LNAI 9002, pp. 1-16): Springer.

Hofstede, G. J., \& Pedersen, P. B. (1999). Synthetic Cultures: Intercultural Learning Through Simulation Gaming. Simulation \& Gaming, 30(4), 415440 .

Hofstede, G. J., Pedersen, P. B., \& Hofstede, G. (2002). Exploring Culture: Exercise, Stories and Synthetic Cultures. Yarmouth, Maine: Intercultural Press.

Hofstede, G. J., Spaans, L., Schepers, H., Trienekens, J. H., \& Beulens, A. J. M. (2004). Hide or confide: the dilemma of transparency. Netherlands: Reed BusinessInformation.

Hofstede, G. J., \& Tipton Murff, E. J. (2011). Repurposing an Old Game for an International World. Simulation \& Gaming, 43(1), 34-50.

Kemper, T. D. (2011). Status, Power and Ritual Interaction; A Relational Reading of Durkheim, Goffman and Collins. Farnham, UK: Ashgate.

Kirkman, B. R., Lowe, K. B., \& Gibson, C. B. (2006). A quarter century of Culture's Consequences: a review of empirical research incorporating Hofstede's cultural values framework. Journal of International Business Studies, 37, 285-320.

Lee, S.-J., Kim, J., \& Park, B. I. (2014). Culture clashes in cross-border mergers and acquisitions: A case study of Sweden's Volvo and South Korea's Samsung International Business Review(online first).

Moeran, B. (2012). Opinions: What business anthropology is, what it might become...and what, perhaps, it should not be. Journal of Business Anthropology, 1(2), 240-297.

Searle, J. R. (1995). The Construction of Social Reality. London: Penguin.

Taras, V., Kirkman, B. R., \& Steel, P. (2010). Examining the Impact of Culture's Consequences: A Three-Decade, Multilevel, Meta-analytic Review of Hofstede's Cultural Value Dimensions. Journal of Applied Psychology, 95(3), 405-439.

\section{Taking Culture Seriously: The Role of Culture in the Study of Business}

Wong Heung-wah (The University of Hong Kong) 
I have been asked to contribute an opinion piece to the Journal of Business Anthropology about the role of culture in the study of business. I myself see the mission of the Journal as a campaign not only to promote a dialogue between anthropologists and management scientists about the study of business, but also to advocate the establishment of business anthropology as a discipline. This way of seeing the Journal's mission, of course, is idiosyncratic and not necessarily agreed upon by the founders of the Journal. However, I believe that it is still worthwhile exploring the theoretical and political issues involved in this two-fold mission, and that is why I am more than happy to accept the invitation.

I think it is important to see the differences between the two parts of the mission. The latter is a political campaign aimed at establishing business anthropology as a new discipline, and so involves a re-allocation of resources within academic organizations, recruitment of personnel, and institutionalization of the field. That is to say, the campaign itself is not just intellectual. I have already explored the political character of the campaign in an invited lecture at Kyoto University in March of this year and I do not intend to repeat what I said then here. I would rather spend the rest of this piece on the first part of my self-claimed mission of the Journal: the role of culture in the study of business.

To ask about the role of culture in the study of business is to ask what the place of culture is in the sociological chain of being. To answer this question involves finding out whether culture can be seen as an independent variable, or as a residual factor to be added to the more basic reason-be it sociological, economic, ecological, or what Sahlins (1976) called practical. The general view among sociologists, economists, and even British social anthropologists is that culture is always a factor secondary to a more fundamental reason for, or logic of, human behaviour. Most sociologists and British social anthropologists (such as Radcliffe-Brown), for example, have regarded culture as something idealistic or ideological, and thus less "real" than something concrete-that is, society or social structure-and it is social structure, they have said, that explains human behaviour. Economists, especially our colleagues from the Chicago School of Economics, tend to argue that culture as a residual factor might change the priority of valuable objects people pursue. But for them the fundamental logic for human behaviour is still the principle of maximization of self-interest. In other words, so far as they are concerned, all human behaviour can be reduced to social structure or maximizing self-interest.

My position is that culture is the essential condition of human existence. In this regard, I would like to point you in the direction of Chapters 2 and 3 in Clifford Geertz's famous book, Interpretation of Cultures (1973); in these he suggested that archeological discoveries proved that the emergence of culture preceeded, and to some extent 
overlapped with, the evolution of pre-human primates into Homo sapiens. That is to say, to contend that pre-human primates become Homo sapiens first, and then created culture, is not correct. Rather, culture is a part of the environment that asserts selective pressure on the evolution of Homo sapiens. It follows from this that the emergence of Homo sapiens is both cultural and biological. In other words, culture is an essential condition of, rather than an additive factor to, human existence.

Another important observation Geertz made in his book is that the major difference between Homo sapiens and chimpanzees lies in the fact that Homo sapiens has a much larger brain than chimpanzee because the former, Geertz argued, needs a larger brain to facilitate culture as a control mechanism to discipline human behavior, while almost all of a chimpanzee's behaviour is genetically determined. I hastily have to add here that culture can not only control but also facilitate human behaviour because it can provide meaning and thus reason for it. Human behaviour is meaningful and takes place in terms of that meaning provided by culture as a symbolic system, which is never the only one possible. No chimpanzee can distinguish a cup of red wine from Christ's blood offered to Christians in church every Sunday because the two are the same chemically. Culture is a species-specific capacity for Homo sapiens rather than an additive factor to something more fundamental for human behaviour.

The important implication of Geertz's excellent argument is that anything human-including business behaviour, economic organizations, and social institutions-has to be cultural, or it is nothing. It follows that the term "cultural" is a redundant word, because everything human is cultural and, more importantly, everything "social", "economic", or "political," is also cultural, because society, economy, and politics are meaningfully constituted.

Understanding culture as a meaningful system that is never the only one possible has several important implications for the study of human behaviour. The first is that different cultures attach different meanings to the same behaviour. Eating dogs is considered cannibalistic in American, but is totally legitimate in Chinese, society because Americans regard dogs as their family friends while Chinese put them in the same category as chickens, pigs, and so on, which are edible. In the context of studying modern corporations, we cannot assume $a$ priori that the meaning of a corporation is the same in every culture.

My early ethnographic research on the Hong Kong subsidiary of a Japanese supermarket, Yaohan (Wong 1999), sheds considerable light on this point, for it discovered that, although the structure and organizational patterns of Japanese companies (kaisha) are similar to those of their Western counterparts, the meaning of kaisha is very different from that of a Western "company." To simplify enormously, in the West, neoclassical economists tend to understand companies as an 
instrument to maximize shareholders' profits, while transactional economists consider them as an effective tool to minimize transactional costs. Japanese people, however, tend to treat the kaisha as an end in itself. All the stakeholders of any one kaisha-including shareholders, management and employees-have to sacrifice their own interests for the continuity and prosperity of their kaisha. This is a far cry from the shareholder profit/transaction cost approach taken by Western economists.

The same research also discovered that when Japanese people borrowed the idea of "joint-stock company" from the West in the Meiji era (1858-1912), they interpreted the idea in terms of their own ie (household) tradition, in the course of which "joint-stock company" was transformed into kaisha. My anthropological conclusion of this research is that in order to have a better understanding of Japanese companies, we need to pay close attention to the native, social (as opposed to economic) concept of kaisha (and we might note here that the two Chinese characters used to write it are the reverse of those used to refer to "society," or shakai). We cannot assume that the term itself is just a translation of the western "joint-stock company," even though the two are similar structurally and organizationally.

The same goes for the study of family business. As far as I know, although family business is assumed in business studies to be different from non-family business and thus deserves a discursive space for investigation, scholars of the discipline seldom take seriously the fact that different cultures have different ideas of family and that, as a result, family businesses in different cultures will display very different forms of organizational behaviour. Take the Chinese and Japanese families as an example. Again, to simplify things enormously, Chinese people tend to emphasize the continuity of the genealogical line of their chia-tsu (family), while Japanese people stress the continuity of the economic aspect of $i e$ (household). This different emphasis on family ideology is also reflected in the family companies in Chinese and Japanese societies. Chinese people do not hesitate to sacrifice the interests of their companies to ensure the continuity of the genealogical line of their family. This is why they will still pass their business to a son, even if he is clearly incapable, or even stupid. This is why family wealth in Chinese societies never lasts beyond three generations. Japanese people, however, will bypass their incompetent sons and hand over a family business to a capable adopted son, and more often to an adopted son-in-law (muko yōshi), in order to ensure that it can continue successfully. It is not difficult to find a small ramen (Japanese noodle) shop that has 300 years of history in Japan. We cannot assume, therefore, that families in different cultures are the same. Neither should we regard family businesses in different cultures as displaying the same forms of corporate behaviour. Again, we have to take culture seriously. 
I am not going to deny that there are and have been some scholars in business studies who pay particular attention to culture. For example, in the 1980s, as we can see in other opinions expressed here, some scholars advocated the idea of corporate culture and argued that the creation of corporate culture could help enhance employees' productivity; others such as Geert Hofstede treated culture as an independent variable, and tried to explain management in terms of cultural traits. The major problem with the former, so far as I myself am concerned, is that they seem to believe that culture can be easily created out of nothing for pragmatic purposes such as profit maximization. This reminds me of what anthropologists have been (mistakenly) arguing about the invention of tradition. All traditions are created-there is no doubt about that-but traditions cannot be created in any way people want. Ethnographic examples from all over the world testify to the fact that traditions are created in terms of culture: so, different cultures, different modes of inventing tradition.

The problems of the second approach are, in my opinion, even more serious. First of all, what I like to think of as "Hofstede Co. Ltd" tends to reduce the complexity of culture to a series of dimensions, and to measure different cultures in terms of these dimensions through questionnaire surveys, in order to delineate the configuration of different national cultures. These are in turn used as an independent variable to explain the differences in management practices across cultures. One of the major problems of this approach is the arbitrary selection of cultural dimensions. We can always come up with different sets of cultural dimensions to classify national cultures differently. Another major problem is that such an approach ignores the intra-cultural differences caused by gender, ethnicity, age, class, and so on. More seriously, Hofstede Co. Ltd presumes a simple cultural determinism that assumes a one-toone correspondence between culture and individual behaviour. But Marshall Sahlins has taught us that there is always a gap between culture and individual behavior, because the conventional value of a cultural category is different from an individual's interest in that category. As he effectively argued (Sahlins 1985: 150; italics in original) :

"The value of a 5 -franc is determined by the dissimilar objects with which it can be exchanged, such as so much bread or milk, and by other units of currency with which it can be contrastively compared: 1 franc, 10 francs, etc. By these relationships the significance of 5 francs in the society is determined. Yet this general and virtual sense is not the value of 5 francs to me. To me, it appears as a specific interest or instrumental value, and whether I buy milk or bread with it, give it away, or put it in the bank depends on my particular circumstances and objectives. As implemented by the subject, the conceptual value acquires an intentional value-which may well be different also from 
its conventional value."

Of course, the personal objectives of individuals and their interpretation of particular circumstances, are both culturally constituted. On another occasion, Sahlins (2004) argued that the family, in which the individual concerned is brought $\mathrm{u}, \mathrm{p}$ has a major impact on how $\mathrm{s} /$ he formulates his or her objectives and interprets his or her particular circumstances. That is to say, the intervention of family is a major reason for the existence of the gap between culture and individual behaviour.

All of this suggests that individual behaviour and culture are phenomena of two different orders: the former cannot be directly reduced to the latter, and vice versa. It follows that individual behaviour cannot explain the configuration of a culture; nor can the latter determine the former. As Sahlins argued, "[j] ust because what is done is culturally logical does not mean the logic determined that it be done-let alone by whom, when or why-any more than just because what I say is grammatical, grammar caused me to say it" (Sahlins 1999: 409). This decisively undermines the simple cultural determinism assumed by Hofstede Co. Ltd.

In short, any theoretical framework through which human behaviour is understood has to consist of three terms: culture, individual behavior, and mediation of the two. Under such a theoretical framework, scientific explanation should consist in showing: first, how individual behaviour is ordered by culture; and second, how and why individual behaviour is not prescribed by culture. Obviously, this scientific operation does not aim to reduce the complex to the simple, in the way that the natural sciences have been doing and are continuing to do. Rather, it aims to substitute a complex picture of human behaviour with another picture produced by researchers which is as complex as, but more intelligible than, the original picture. I believe this is what good anthropologists have been and are doing. What the anthropologist does in ethnography is to reproduce in his or her mind the cultural logic displayed in the behaviour of the Other that s/he observes in the field (Sahlins 2000). This competence in reproduction of the cultural logic of the Other can be attributed to the common species-specific capacity: culture. In other words, for the study of human behaviour, the method and the object of study are the same. The researcher and the object of study have the same ontological status. In the study of nature, on the other hand, the researcher is a species with symbolic ability and the object of study is not. Thus the basic assumption of the distinction between subject and object may not be applicable to anthropology.

The implications of this argument are several. Any understanding of human behaviour involves human subjective reproduction of the cultural logic of the Other by the researcher. It follows that the general impression we generated from natural science that "objectivity" is a critical criterion that guarantees the "trueness" of research results may not be applicable 
to the study of human behaviour. Secondly, if we agree that by reproducing the cultural logic of the Other, we make the Other familiar and thus understandable, it follows that we should understand the Other subjectively from within. This notion of understanding is very different from that found in natural science, which tends to start from an opposite standpoint; that is, understanding natural things objectively from outside. As Sahlins (2000: 30) argues:

"Indeed, the more we know about physical objects the less familiar they become, the more remote they stand from any human experience. The molecular structure of the table on which I write is far removed from my sense of it-let alone, to speak of what is humanly communicable, my use of it or my purchase of it. Nor I will ever appreciate tableness, rockiness, or the like in the way I might know cannibalism. On the contrary, by the time one gets to the deeper nature of material things as discovered by quantum physics, it can only be described in the form of mathematical equations, so much does this understanding depart from our ordinary ways of perceiving and thinking objects.

The reason anthropologists can understand the Other is because we and the Other are the same: both of us have culture. That is to say, culture is both our genesis and our tool to understand the Other. Or, culture is what constitutes our business organizations and management behaviour and also our tool to understand those forms of organization and behaviour.

\section{References}

Geertz, C. 1973 The Interpretation of Cultures. New York: Basic Books.

Sahlins, M. 1976 Culture and Practical Reason. Chicago and London: The University of Chicago Press.

Sahlins, M. 1985 Islands of History. Chicago and London: The University of Chicago Press.

Sahlins, M. 1999 Two or Three Things that I Know about Culture. The Journal of the Royal Anthropological Institute, 5(3), 399-421.

Sahlins, M. 2004 Apologies to Thucydides: Understanding History as Culture and Vice Versa. Chicago and London: The University of Chicago Press.

Wong, H. W. 1999 Japanese Bosses, Chinese Workers: Power and Control in a Hong Kong Megastore. Richmond: Curzon Press. 